\title{
Skin-derived tumor specific T cells predict clinical outcome in dendritic cell vaccination studies in both stage III and IV melanoma patients
}

\author{
EHJG Aarntzen, W J Lesterhuis, M Van Rossum, G J Adema, C F Figdor, CJA Punt, IJM De Vries \\ From 5th European Workshop on Immune-Mediated Inflammatory Diseases \\ Sitges-Barcelona, Spain. 1-3 December 2010
}

\section{Introduction}

Dendritic cells (DCs) are the professional antigenpresenting cells of the immune system. Their decisive role in inducing immunity formed the rationale for DC immunotherapy: DC loaded with tumor antigens are injected into cancer patients to stimulate $\mathrm{T}$ cells to eradicate tumors.

\section{Aim}

To improve immunotherapy against cancer, adequate tumor specific immune monitoring is essential. Here, we evaluate our monitoring tools to predict clinical outcome to DC-based vaccination in melanoma patients.

\section{Patients and methods}

In our ongoing trials, HLA-A2.1 positive stage III and IV melanoma patients are vaccinated with DC loaded with gp100 and tyrosinase and control antigen keyhole limpet hemocyanin (KLH). Routine monitoring consisted of KLH specific responses in peripheral blood and tumor specific response in blood and cultures from DTH site biopsies.

\section{Results}

Upon vaccination, almost all patients showed proliferative and humoral responses to KLH. Tumor specific CD8 $+\mathrm{T}$ cells are rarely detected in peripheral blood and coincided with the presence of tumor specific CD8 $+\mathrm{T}$ cells in DTH site cultures [1]. We show the strong predictive value of presence of functional tumor specific CD8+ $\mathrm{T}$ cells in DIL cultures for PFS and overall survival (OS)

Dept. of Tumor Immunology and Medical Oncology, Nijmegen Centre for Molecular Life Sciences, Radboud University Nijmegen Medical Centre, Nijmegen, The Netherlands in metastatic melanoma patients, and show similar significant correlation for PFS in stage III melanoma patients.

\section{Conclusion}

Monitoring of KLH specific proliferative responses or tumor-specific $\mathrm{T}$ cells in peripheral blood was not predictive for improved clinical outcome. Our findings show that the presence of functional tumor-specific $\mathrm{T}$ cells in DTH site biopsies predict clinical outcome.

Published: 25 November 2010

\section{Reference}

1. De Vries IJM, Bernsen MR, Lesterhuis WJ, Scharenborg NM, Strijk SP, Gerritsen MJ, Ruiter DJ, Figdor CG, Punt CJ, Adema GJ: Immunomonitoring tumor-specific T cells in delayed-type hypersensitivity skin biopsies after dendritic cell vaccination correlates with clinical outcome. J Clin Oncol 2005, 20:5779-5787.

\section{doi:10.1186/1479-5876-8-S1-I3}

Cite this article as: Aarntzen et al:: Skin-derived tumor specific T cells predict clinical outcome in dendritic cell vaccination studies in both stage III and IV melanoma patients. Journal of Translational Medicine 2010 8(Suppl 1):13.

Submit your next manuscript to BioMed Central and take full advantage of:

- Convenient online submission

- Thorough peer review

- No space constraints or color figure charges

- Immediate publication on acceptance

- Inclusion in PubMed, CAS, Scopus and Google Scholar

- Research which is freely available for redistribution 